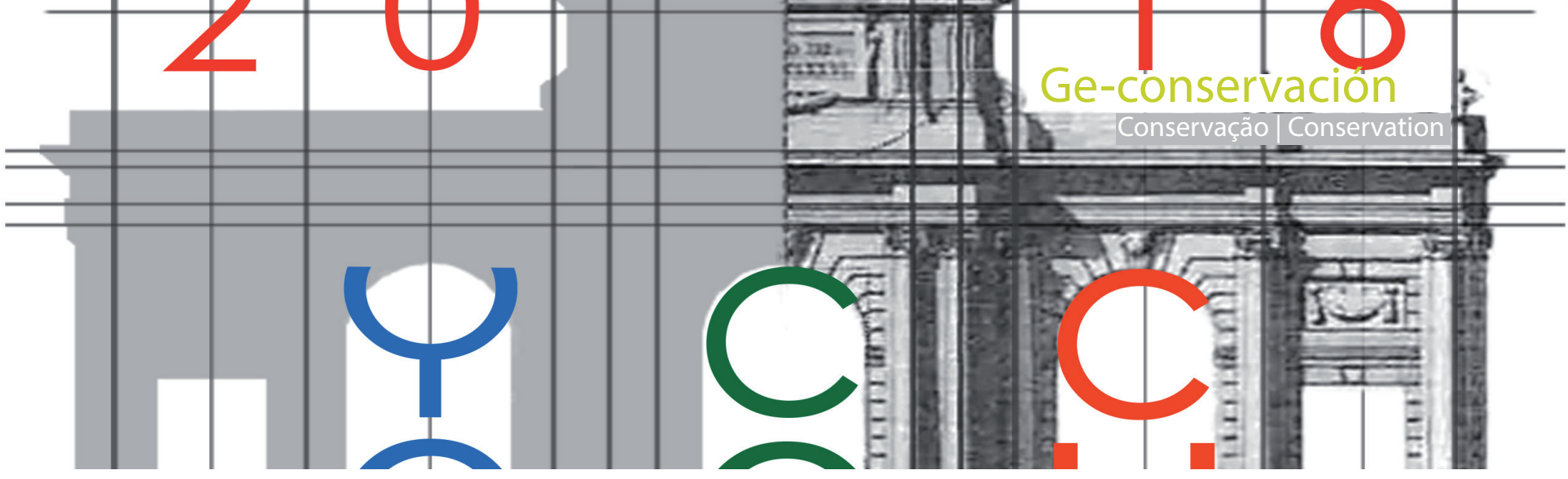

\title{
The utility of the application of new three-dimensional technologies for the study and dissemination of heritage from a historical-technical perspective: case studies
}

\author{
Irene Ruiz Bazán, Gianluca Emilio Ennio Vita
}

\begin{abstract}
In this article we analyse the different applications of convergent photogrammetry in three different cases. In the first one, the application in the beginning of a restoration project of the Chapel of the Purification in the Church of the Carmine in Milan (Italy), where we will explain the usefulness of this technology. In the second case the utility of the three-dimensional reproduction made to the hidden murals at the Collegiate Church of Santa Maria in Daroca (Spain) for its diffusion and finally the application of this technique as a tool for communicating the results of research in projects. The confrontation of these cases in which the same technology is applied at various stages of the process of conservation and study of heritage, with distinctly different purposes, aims both to deepen their usefulness, such as delineating its limits and requirements
\end{abstract}

Key words: convergent photogrammetry, building restoration, 3D model, heritage research.

\section{Utilidad y aplicación de las nuevas tecnologías tridimensional en el estudio y difusión del patrimonio desde una perspectiva histórico-técnica: casos de estudio}

Resumen: En este artículo, analizamos las diferentes aplicaciones de la fotogrametría convergente en tres casos diferentes. En el primero, la aplicación de esta en fase de redacción de proyecto en la intervención de restauración de la capilla de la Purificación en la Iglesia del Carmine en Milán (Italia), dónde explicaremos las utilidad de estas restituciones. En el segundo caso se analizará la utilidad de la reproducción tridimensional realizada a las pinturas murales ocultas en la Colegiata de Santa María en Daroca (España) y por último se planteará la aplicación de esta técnica como instrumento de difusión de las investigaciones realizadas en proyectos de i+D+i. La confrontación de estos casos en los que la misma tecnología se aplica en diversos momentos del proceso de conservación y estudio del patrimonio, con fines claramente distintos, pretende tanto profundizar sobre su utilidad, como delinear sus límites y los requisitos que estas restituciones deberían satisfacer.

Palabras clave: fotogrametría convergente, restauración arquitectónica, modelo tridimensional, investigación en patrimonio.

\section{Introduction}

In recent years the field of cultural heritage has become one of the undisputed protagonists in the development of three-dimensional technology. Although this technology was not born for this application to heritage, its use in the field is demonstrably increasingly inescapable.

The use of three-dimensional technology for the reproduction and modelling of cultural heritage buildings is continually increasing. It is not far from reality to suggest that this technology will be used, in the very near future, in all conservation and restoration projects in Europe.
The advantage of this technology at all phases of conservation, development and diffusion of our cultural heritage is self-evident. In this article we present three different works employed as case studies to illustrate this situation, and consider the relevance of using new technologies and their relative usefulness at every phase of the conservation of heritage from a historical-technical perspective. We currently have access to very powerful technology that, most of the time, is not accompanied by the necessary theoretical and practical reflection on its use which would optimise its use and extend the possibilities it offers. We intend to bring to light the need for a critical analysis of its use which should precede any realisation. 
We shall discuss shortly the diverse applications of threedimensional techniques in different cases.

The confrontation of these cases with distinctly different purposes is intended to clarify and offer new perspectives on their usefulness, such as delineating the limits and requirements of the technology (Pérez Zapata, 2006).

The first case study is the Purification chapel of the church of Santa Maria del Carmine in Milan. It follows the model designed by Bramante and consists of a hemispherical dome supported by a drum sustained by pendentives. The decoration of the ceilings, columns and spandrels is both decorative and figurative; painted surfaces are primarily in the technique of fresco while decorating the high and bas-relief is plaster stucco with gold leaf. The decorative project responds to a unitary project attributed to the painter Giovanni Mauro della Rovere, "The Fiammenghino". The sponsor of the work is the parish in cooperation with Fondazione Cariplo funding.

The second case study is the Collegiate Church of St. Mary of the Body of Daroca Sponsored by the Fundación Campo de Daroca. It is, like most of our heritage, the result of several phases of construction at different periods.

The early church had a semi-circular apse facing east, which became a chapel during the Renaissance reform. The primitive apse remained hidden by a new vault.

During the restoration of the Collegiate church carried out in the nineties by architects Fernando Aguerri and Javier Ibargüen, an access was built through a metal staircase from behind the altarpiece of the new chapel, which allows access to this area. Due to the physical characteristics of the space, this access is too narrow and it is not possible to allow public access, therefore depriving visitors of the possibility of enjoying those mural paintings, about the existence of which, unless the guides offer precise indications, visitors remain unaware.

Finally, we present a case in which the application of technologies of three-dimensional reproduction has a strong educational and informative character which provides to the general public useful and comprehensible results of $R+D+I$ research, conducted with public funding. Those projects are: Restoration and monumental reconstruction in Spain 1938-1958. The General Directorates of Fine Arts and Devastated Regions (Ref. HUM2007-62699), financed by the Ministerio de Ciencia e Innovación, and continued by the project Monumental Restoration and Development in Spain 1959-1975, (Ref. HAR2011-23918), financed by the Ministerio de Economía y Competitividad; and the last one, Restoration architects in Spain during the Francoist regime. From the continuity of the 1933 law to the reception of the European theory, Ref. HAR201568109-P (2015-2019), financed by the Ministerio de Economía y Competitividad, Secretaría de Estado de Investigación, Desarrollo e Innovación and FEDER founds. The principal researcher is María Pilar García Cuetos, an instructor at the University of Oviedo (Spain). These cases have been presented in the Congress Book of the " 5 th International Conference
Youth in Conservation of Cultural Heritage YOCOCU 2016". Madrid: MNCARS, Ruiz Bazán and Vita (in press).

\section{Methods \& methodology}

-Three-dimensional reproduction of the mural paintings of the chapel of the Purification in the church of Santa Maria del Carmine in Milan (Italy).

We have a case where the three-dimensional restitution is made in draft form using the technique of convergent photogrammetry (restitution of geometry by performing conventional photographs that are interpreted by a computer programme which also generates a three-dimensional model texture-mapping —applied to it) García León (2008). The preference for using this technique rather than others, such as a laser scanner, is because we are obtaining a map of faithful colours applied to a three-dimensional model which is essential for our purposes and the cameras of the scanner do not allow us to obtain a final quality result. Conventional digital photography applied in this system allows us to perform white balance, and all necessary corrections before making photographs, thus giving us a high quality texture.

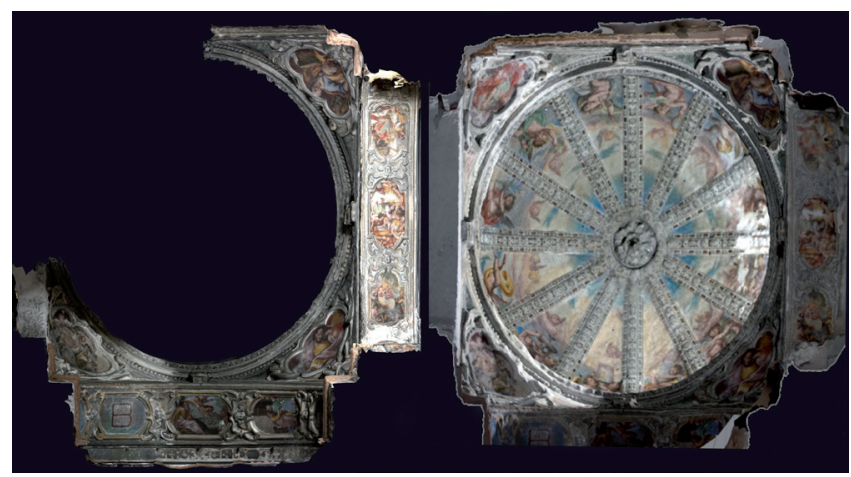

Figure 1.- Orthophotograph made from the three-dimensional model of the dome of the Purification Chapel of the church of Santa Maria del Carmine in Milan, Italy.

The main advantage of this system lies in the possibility of obtaining a complete model of the interior of the architectural space which also reveals its physical characteristics and allows us to work in three dimensions to obtain all projections of space we need to develop plans, elevations and sections, damage maps, typological classifications and intervention proposals.

This ability to get as many orthophotographs (photographs that present an orthogonal projection without perspective effects) [figure 1] allows us to get a complete documentation of the place. Thus we can directly measure flat surfaces and get almost immediately the dimension of curves, such as vaults and domes, which allows a degree of accuracy that is almost impossible to date project measurements, especially when, as in the case we are presenting, we still do not have mounted scaffolding that can reach all points that need to be studied. 


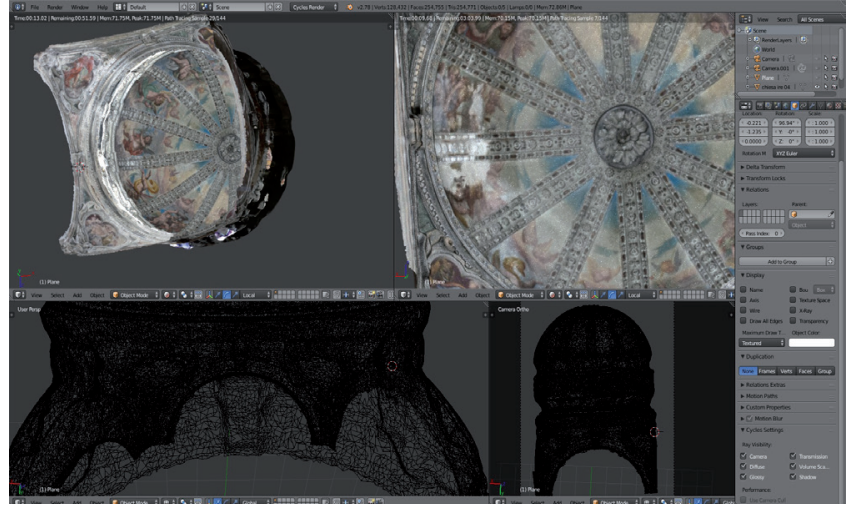

Figure 2.- Three-dimensional model of the dome mapped, shown inside the Blender $3 d$ Open Source software. They are visible some parts deformed in the lower part of the dome. Given the complexity of the model and the presence of numerous points unreachable to the camera, it was necessary the realization of more models and the subsequent unification.

With this material, it is possible to create very accurate plans for the mapping of materials identification, damages, diseases and intervention proposals.

For this work we have used the photographs taken with a full frame sensor camera with 20.2 megapixels (Canon EOS 6D) and processed on a computer with Intel i7 processor and 32 GB of RAM supported by the graphics card Nvidia $3 \mathrm{~GB}$. The model obtained is suitable for the reproduction of mural paintings and the orthophotos obtained with the $3 \mathrm{D}$ model programme (Blender $3 \mathrm{D}$ ) with the option to be printed at 300 ppi in A3.

Moreover, the realisation of a realistic three-dimensional model of the chapel can be extremely useful for the communication, perception and comprehension of issues related to the chapel and its paintings and sculptures for both visitors and researchers.

The possibility of viewing the model of the interior of the chapel with a realistic mapping of the paintings from an infinite quantity of points of view and with the full capacity of rotating and moving from bottom to top would be a stunning experience.

Proportions, relations between interior and exterior spaces, light and colours are perceived in a totally different way in comparison with a traditional representation, and also in comparison with the point of view that a visitor can have from the ground level.

Compared with the traditional way of representing ancient buildings, there are two great opportunities that this kind of representation can give to all of us. The first is the possibility of having a hyper-realistic mapping of the object. The surface of the model is no longer an abstraction, but is real (as real as a digital photo can be).

A very important fact is that the three-dimensional model is not realised starting from drawings and then painted, as in all previous physical or virtual traditional models [figure 2]. The model is extracted from photos, as is the mapping that creates the model. It is the paint that creates the volume and the virtual space. This changes not only the process but also the perception that we can have of an ancient building.

This fact is obviously incredibly important when we think about the model as a document for the future. In the case of future restorations or research, to have the possibility of knowing the exact appearance of the building 10,50 or 100 years before, could be crucial.

The second opportunity is to have a model that you can navigate. Despite the fact that at the moment the technology to navigate inside a three-dimensional model is not suitable for all, we are sure that this will be part of the future of our heritage.

\section{-Three dimensional model of the romanesque apse paintings} in the Collegiate Church of Daroca (Spain).

In this case, the use of the technique of reproduction by convergent photogrammetry, using the same technology we have explained, is absolutely suitable for the reproduction of mural paintings and could be used for further study of these paintings or just to display to the general public. The advantage of this type of reproduction versus traditional photography is the fact that having all the documented space in a single file [figure 3] facilitates the understanding of the programme of mural painting and its context, and is extremely useful for paintings preserved in situ.

The three-dimensional reproduction in this case opens up new possibilities for the study and diffusion of these paintings; it is possible to have all the space documented and to browse inside, allowing one to zoom in on the areas to study in detail, with the only limit of accuracy being that which has been applied to make the model (the accuracy convergent photogrammetry is defined by the detail we can see graphically and is determined by the relationship between the pixel size, the distance at which the photography has been taken and the focal distance employed).

-Use of three-dimensional models for diffusion of the results of $A R+D+$ I research

Finally, we present a case, recently approved in its third phase and not yet realised, in which the application of three-dimensional reproduction technologies has a strong didactic and divulgative character for communicating to the main public the results of the three research projects.

These projects are intended to contribute to "cover the patent historiographical deficiency in knowledge of the conservative, reconstructive and restorative activity under the Francoist period from the 1950s and over the decades of the 1960s and mid-1970s, which concludes with the 


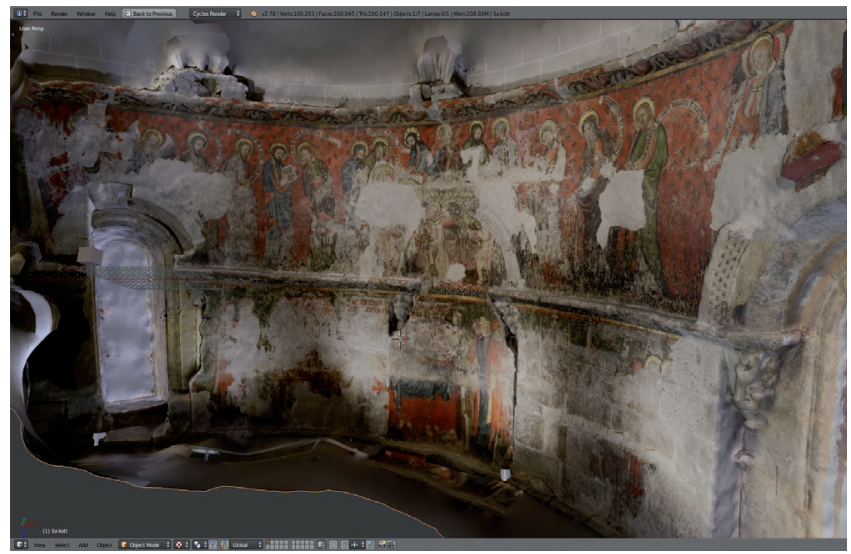

Figure 3.- Three-dimensional view of the mural paints of the Collegiate church of Daroca made by convergent photogrammetry.

death of General Franco" General Franco" (García Cuetos, 2013). The results of those researches have been collected in numerous publications, the most important of which are: Restaurando la Memoria, España e Italia ante la recuperación monumental de posguerra (García Cuetos, 2010) and Historia, restauración y reconstrucción monumental en la posguerra Española (García Cuetos, 2012). In addition to those books, numerous scientific articles and conference proceedings of congresses have been published, which are, however, directed to a specific public.

The results of these investigations have shed new light on the authenticity of the various phases of the monuments from which we have been able to establish broadly that many of the monuments restored during this period underwent profound changes. They underwent both additions and the removal of architectural elements under the guise of returning them to their "original" state, and intended as a glorious image of ancient Spain.

So, lots of information on what those buildings once looked like has been lost. Instead of this, there were created a number of new additions that could be termed "historically false" that today, due to lack of visual notoriety with which they were made, are difficult to understand (despite the principles of the Charter of Athens and the subsequent Historical Heritage Law promulgated in Spain in 1933 and applicable till the new one was made in 1985, which prohibited reconstructions and, only in the case of extreme necessity, allowed them with the condition that the additions made were always recognizable).

The three-dimensional model made with descriptive intent and not as a faithful reproduction of reality, will allow the different phases of construction and restoration to be distinguished, as well as the lost parts from both inside and outside of buildings to be virtually recreated, which in most cases belong to the baroque period. The appearance of the building during each historical phase will help to increase the knowledge and awareness of what happened during the study period. To carry out this work, we have the original plans on a scale of $1 / 50$ and $1 / 100$, the ancient photographs and the possibility of making a model using convergent photogrammetry of the building in which we add to or remove from a 3D model programme, such as Blender 3D, all the elements we need in order to clarify the different processes of the restoration. The development of these models becomes essential for communicating to the general public the results of this research because the vocabulary used in the written descriptions, specific to the field of art history, the restoration of monuments and architecture, is not easily understood by those who do not have specialised training. Moreover, threedimensional objects are more easily understood because they don't require the effort of abstraction that a plant or section needs for its interpretation. That is why the realisation of these three-dimensional reproductions will culminate those investigations, which could be used for both informative panels or audiovisual media installed on the monument itself, as itinerant exhibitions or other communication systems capable of bringing to the public the results of the investigation.

\section{Discussion}

This article has sought to illustrate the practical use that today we can make of the technologies of restitution and three-dimensional reproduction, especially convergent photogrammetry, applied to the field of heritage management with different scopes: one before an intervention, one when the intervention has already been made several years ago but its results are hidden to the public, and finally when the aim is to communicate to the public the results of a historical research. We have seen how the time at which this technology is utilised changes its utility and its possibilities of being used. Thus, from a better and faster development of the restoration project, we can see the first uprising of these technologies. We have also seen their value as a documentation tool of the current status that could be replayed artificially if necessary. Once the three-dimensional model is complete it could become a very useful tool to facilitate accessibility of the results to the public and researchers who may need these models for consultation purposes. It is precisely this point, the accessibility of these models, which opens today a further discussion surrounding the application of these technologies. Thus, practically as noted above, a large number of the projects of a certain size that have been undertaken in Europe are documented using these techniques, but access to these models is still difficult and often impossible.

\section{Conclusions}

The first key issue is to establish a unified format for the three-dimensional models that allows for opening the file from standard programmes. We may establish parallelism between the swap file and pdf file (portable document format) the use of which today can be considered 
universal, and so facilitating the use of these files for any researcher or user wanting to perform only consultation should be brought about so that anyone can open them without having to install a three-dimensional modelling programme. In this regard, it seems that the latest trends use a pdf format or 3D WebGL HTML 5 accessible from an internet browser, although, as noted, there are so far no rules or protocol regarding the type of file to use to save these views, or on the characteristics they should have, such as the precision, scale of assessment, number of polygons, colour control, etc.

Beyond the problem of non-standardised and regulated formats, we find that there is no unified database in which we can place these models. In this field, it should be noted that 3D-ICONS, a European project, aims to digitalise a number of key pieces of architecture and archeology to provide three-dimensional models. Related to this project, Europeana, the European Union platform for cultural heritage, gives access to different types of content from diverse heritage institutions and CARARE, a network of "best practices", brings together agencies responsible for heritage management and heritage organisations, archaeological museums, research institutions and archives all over Europe to make digital content interoperable with Europeana.

Another remarkable project promoted by the European Commission in this regard is 3D-COFORM which aims to establish three-dimensional documentation as an affordable, practical and effective mechanism for the longterm documentation of tangible cultural heritage. In order to do so, 3D-COFORM proposes an ambitious programme of technical research, along with practical research in the market of three-dimensional views to inform and accelerate the deployment of the use of these technologies.

The implementation of these new technologies in heritage management tends to reach a horizon of extension for its use and standardisation of its formats, but at this moment, that purpose is still a desire and not a fact. At the moment these models are specific realisations, the application of which depends on the criterion of the different professionals of the entities in charge of our heritage. Therefore, there is so much work to be done before we can affirm that these new technologies are implemented properly in the management of our heritage. For now, we can affirm that, so far, its potential exceeds our ability to manage it, since we haven't been able to define standards that allow not just its application to a specific case-drafting project documentation parts, media material, etc.-but to for it to become part of all the processes involved in management. It should be useful from the first moment, facilitating a good conservation project till its last public release, always remaining available to those who could need the three-dimensional reproduction for their studies. If it constitutes an essential reference material, that can facilitate future interventions.
On the other hand, with the appropriate guidance of technicians and competent historians, another use for the development of these new technologies is to materialise or visualise hypotheses about the construction process of these historic buildings. So deep is the geometric knowledge that these technologies offer us, that the possibility exists to "undo the process" that led the monument back to its original statechecking measures, canons, etc.- - to try to confirm some hypotheses. This, however, must be endorsed with studies in other disciplines, such as materials characterisation and particularly the great work of archival research and subsequent contrasts to the existing research, which are certainly fundamental to properly characterise the monument.

\section{Bibliography}

GARCÍA CUETOS, M.P., ALMARCHA NÚÑEZ-HERRADOR, M.E., HERNÁNDEZ MARTíNEZ A. (2010) Restaurando la memoria, España e Italia ante la recuperación monumental de posguerra, Oviedo, Trea.

GARCÍA CUETOS, M.P., ALMARCHA NÚÑEZ-HERRADOR, M.E., HERNÁNDEZ MARTÍNEZ A. (2012), Historia, restauración y reconstrucción monumental en la posguerra española, Madrid, Abada.

GARCÍA CUETOS, M.P., (2013) “La Historia del arte como ciencia aplicada al patrimonio", e-rph no 13, pages 225-252.

GARCíA LEÓN, J. (2008) "Principios y aplicación de la fotogrametría convergente en la fotogrametría arquitectónica", EGE: revista de expresión gráfica en la edificación, №5, pages 110-114.

PEREZ ZAPATA, C. (2006) "Aplicaciones de la fotogrametría convergente en la restauración y rehabilitación de edificios", I Jornada de Investigación en la Edificación", Madrid, Universidad Politécnica de Madrid.

RUIZ BAZÁN, I. VITA, G. E. E. Case studies of the utility of the application of new threedimensional technologies for the study and diffusion of heritage from an historicaltechnical perspective. In: Congress Book of the "5th International Conference Youth in Conservation of Cultural Heritage YOCOCU 2016". Madrid: MNCARS (In press). 


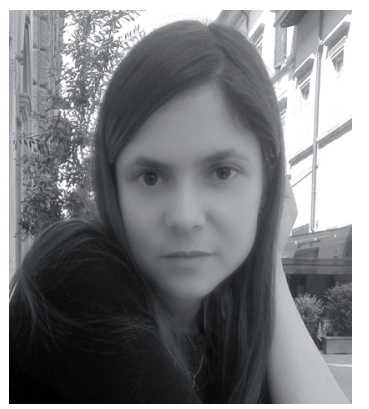

\section{Irene Ruiz}

ireneruizbazan@gmail.com

Irene Ruiz holds a PhD from the University of Zaragoza, a technical architect, MsArch in Building Restoration and has studied Photography in the Accademia di Brera (Milan).

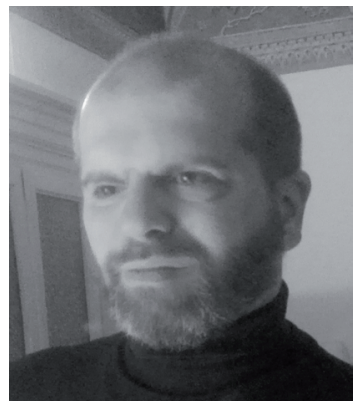

\section{Gianluca Emilio Ennio Vita}

gianluca.vita@gmail.com

Gianluca Vita is teacher both in the Politecnico di Milano and in the Accademia di Brera, he teaches 3D design and both authors have a long work experience in building restoration projects. 